\author{
${ }^{1}$ Prodanova N.A. ${ }^{2}$ AskarovaZh.A., ${ }^{3}$ Kyzdarbekova A.S. \\ ${ }^{1}$ Doctor of economic science, professor Plekhanov State University, Moscow, Russia \\ ${ }^{2}$ Candidate of Economic Sciences, Senior Lecturer, al-Farabi, \\ Kazakh National University. al-Farabi, askarova75@mail.ru \\ ${ }^{3}$ Master of Economic Sciences, University Lecturer, al-Farabi Kazakh National University, aseta_ks@mail.ru
}

\title{
ANALYSIS OF BUSINESS MODELS
}

\begin{abstract}
The term "business model" has been used in practice for several years, but companies create, define and implement their models subconsciously from the very beginning of the business. The article discusses the concept of a business model and the main approaches to its understanding. A systematic presentation and analysis of the business model of the enterprise, the influence of classifiers on the implementation of the life of the company. It is shown that the analysis of the relationships between the main elements of the business model allows us to identify problems of co mpliance and sustainability of the business model. The most general scheme for a systematic description of a business model can be its representation through system elements. The value of the study lies in the fact that a model for the use of a business model is defined. The practical significance of the study is to create an analytical tool and analysis of a real business model, and the characteristics of each part of the business model, that is, customers, distribution, cost, resources, activities, costs and revenues are determined. The value chain is one of the central concepts of strategic management, which was first presented in the works of M. Porter. As you know, the value for the consumer is created in the company as a result of two types of activities (main and auxiliary). The conclusion discusses the most commonly used characteristics, extremes, inconsistencies and the most important facts that were found in the study.

Key words: business, model, economy, enterprise, analysis, sales income, efficiency, asset management, net profit, capital.
\end{abstract}

Introduction. Modern ideas about the business model are based on fourofits elements: what(proposed value), who (target consumers), how (mechanism for creating and offering value to the consumer ) and why (mechanism for extracting and assigning income from the sale of value to the consumer). The strategic and operational models that reflect the nature of the decisions made by the company are highlighted. Within the framework of the first, elements such as: value proposition, consumer segments, key resources, key activities are derived. In the framework of the second, an operational model is derived: logistics, marketing support for activities and sources of commercial effect. A schematic diagram of a business model through the prism of the concept of social entrepreneurship in the context of target groups has been developed. This approach combines the simplest model scheme, consisting of 4 elements, and an inclusive approach to social entrepreneurship, reflecting the role of target groups in the model. The authors noted that the peculiarity of constructing business models in social entrepreneurship is that the theory of social impact is the basis of any model. This concept puts the creation of a social effect at the center of any organization and considers it to be a value equal to the economically created value. Since the 1990s, the term "business model" has been steadily present in scientific research on the corporate sector of the economy, which has not been filled with a single empirical content for a long time, but rather has the character of generalizing the company's main market idea and its strategy. The business model most often refers to innovations related to a technology, product or business process, since the innovative potential of a company has long been expressed precisely in a product, technology or process, and these elements of a business idea were in focus. In a certain sense, this is the case now. Logically, the category of a business model is associated with such concepts as corporate strategy, business process and value chain. Combining these concepts in a single logic, we can say that a corporate strategy determines its empirical projection or business model, which is a business process for creating a value chain.

Literature review. Many authors note that the term "business model" was widely used after 1995. Moreover, they divide the period of the emergence of business models into three stages. The first stage is seen as the stage that accompanies a sharp change in business culture towards the digital economy. At the second stage, relations are established between the concepts of "business model" and "strategy", "business model" and 
"productivity", "business model" and "innovation, opportunities and resources". And finally, the third stage is characterized by a high growth of competition among enterprises.

According to Zott and Amit, the business model has become popular amid the growth of the Internet. People understand that in the framework of globalization, accelerating technological changes, the business environment is more uncertain, while business models in the enterprise are the most important success factor. A business model of innovation can bring a strategic competitive advantage; an enterprise should be able to develop in the new economic environment. An innovative business model is considered a new management template and has many valuable innovative technologies, which makes the company competitive.

Da Silva and Trkman note that the term has not been widely used for several decades. There were few peer-reviewed journal articles on the topic of "business model" (about five) until the 1990s. With the development of information and communication technologies (ICT) and the advent of Internet companies, the term quickly gained fame not only among practitioners, but also among business scientists. The authors acknowledge that during this period, terminology has spread across various communities, such as marketing, management, banking, and ICT, and is used in various contexts such as a business plan, business strategy, value creation, globalization, and design organization.

Onetti with co-authors concluded that the growing interest in business models coincided with the advent of e-business in the mid-1990s. At that time, many new young businesses began to develop Internet offers. Rapid technological changes in this new business era have led to dramatic changes in competitive approaches in many industries. Johnson and his colleagues noted a growing interest in the business model in 2008 (Afuan H 2003:38). This interest has become more intense than in recent years. The authors note that the relevance of business models has increased thanks to Internet technologies, without which it is currently impossible to imagine business development. Chesbrough suggests that the right use of advanced technology and other driving forces can completely replace innovation: "Mediocre technologies implemented in a big business can be more valuable than creating innovations. "Scientists are exploring various aspects of new business models - from how companies operate due to changes in the supply chain structure, to advertising and sponsorship receipts from other firms. Voelpel, Leibold and Tekie note that business models have evolved with the advent of:

- information technology with the ability to process large amounts of data;

- a virtual space in which more and more economic transactions are taking place;

- increase the return on knowledge and intellectual (intangible) assets;

- Innovation as the main resource for creating value.

Material and Methods. The term business model comes from financial journalist Michael Lewis, who in his articles predicted that future companies will be based on business models that are only related to the Internet. Business models on the Internet are both simple and complex. A simple model is the concept of an online retailer - a company purchases goods and uses online channels to sell them and increase business awareness. According to a more complex model, large information portals work - they see many options for monetization (starting with the sale of advertising inventory, ending with writing custom materials), which requires an analysis of the sources of profit and their optimization in order to increase revenue.

In the current period of time, it can be stated that for online commerce not only unique business concepts were created, but also traditional ones were effectively optimized. Take, for example, an auction - one of the oldest forms of brokerage has been significantly improved due to many marketing concepts, the simplest of which are the principle of urgency and the effect of limitedness. As a result, marketers managed to create an effective, gamified system that engages consumers in the bidding process and increases their readiness for high costs.

One of the most popular online auctions is eBid - more than 3605100 products with a total value of more than \$2 640499271 are placed on the site.

A more modern model that has developed over the past 16 years is SaaS (Software as a Service, software as a service) - the sale and use of a software solution in which the provider develops and optimizes the cloud application, providing the customer access to it via the Internet.

David Teece believes that "the business model still does not have a clear theoretical foundation in the economy . "It is very difficult to distinguish those processes and components that are necessary for the business and would determine the creation of value in the company comprehensively and fundamentally. 
Some authors define a business model as a system of making money. In their opinion, a business model is an economic concept that "generates " income and expenses. This is a set of activities that create profit through the interaction of processes and technologies. Definitions of authors considering a business model as an economic concept are presented in SmartArt 1 - Picture 1:

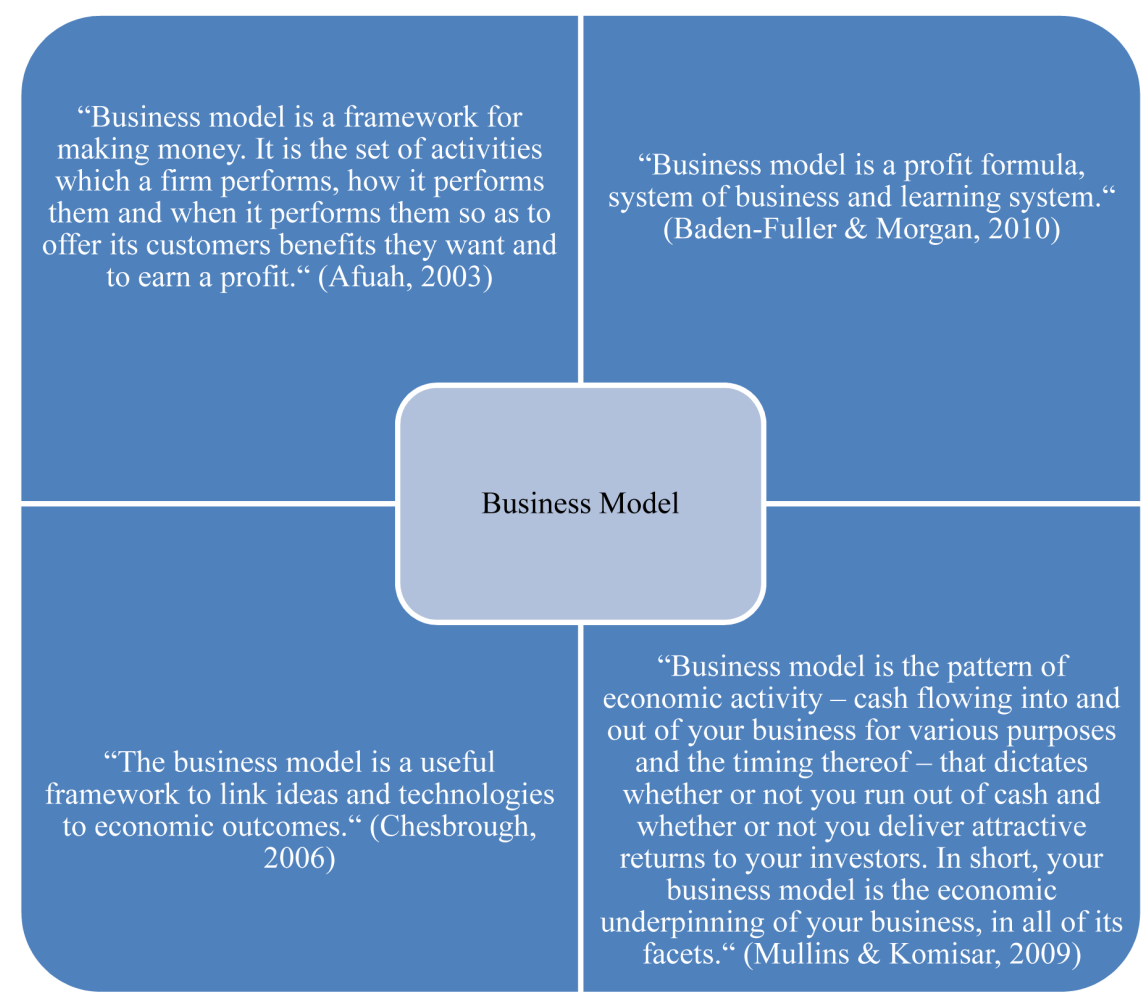

Picture 1- Economic business model

A purely economic view of the business model does not constitute a complex view of the company.

The business model should (with the exception of production income and costs) cover the other side of the business, and it creates value. Below are the opinions that view the business model as a combination of an economic and value outlook.

David Watson - "The business model describes the company's activities, including all its components, functions and processes, which lead to costs for itself and cost to the client."

David J. Teece - "A business model defines how a company delivers value to a customer and translates payments into profits ."

Joan Magretta - "Business models are, in essence, stories that explain how enterprises work. Like a good story, a robust business model contains welldefined characters, plausible motives, and a plot that includes an understanding of value. He answers certain questions: Who is the customer? How do we make money? What basic economic logic explains how we can deliver value to customers at the right price? ".

We believe that a business model is a system of resources and activities that create value that is useful to the client, and selling this value brings profit to the company. The purpose of the analysis of business models is to deepen and expand knowledge about the main components of a business model. We see the importance of this goal in enhancing the functionality and efficiency of business models, as well as in identifying and developing competitive advantages that can be discovered with the companies themselves.

According to John Mullins and Randy Komissar (2009), a successful business model is based on five models that determine the economic viability of a business (SmartArt 2) - Picture 2: 


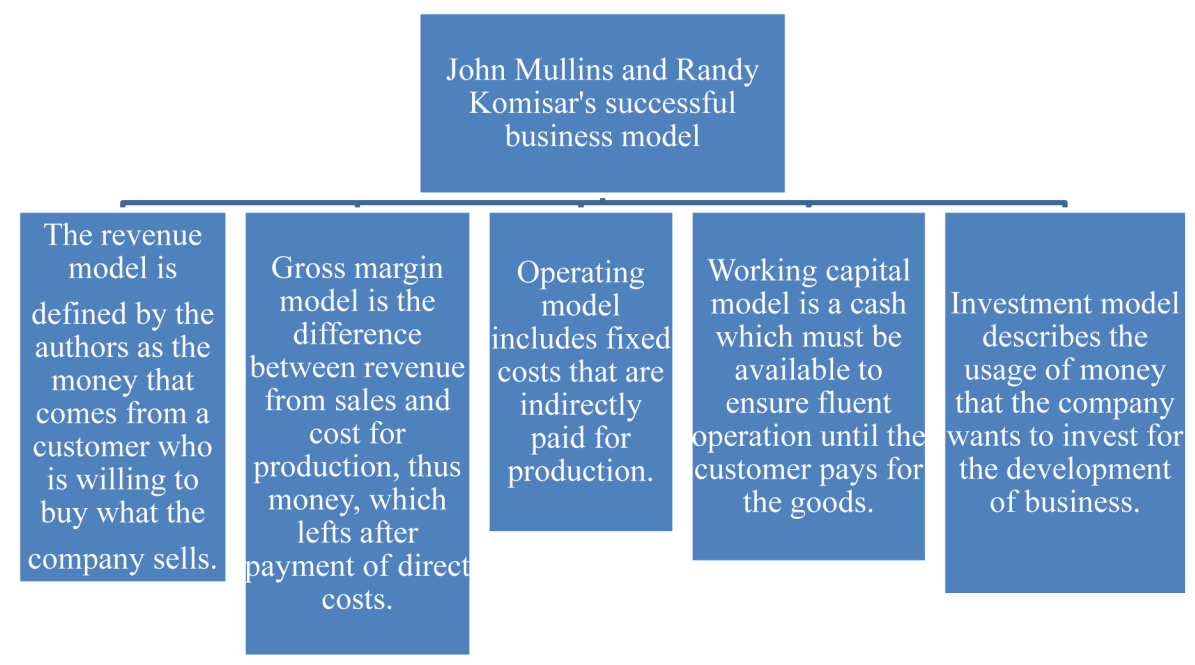

Picture 2 - John Mullins and Randy Komisar's successful business model

The recipe for a successful model is the harmony of all five models, which helps to be more effective and this harmony creates value for customers and profit for the company. A successful company is one that, after paying gross profit, operating expenses, operating capital and investments, still has free money. A positive mathematical result is a sign of success in the present and, probably, in the future. This concept can be applied to analyze business economics and assess financial health, but it abstracts from other components of the business model. This model pays little attention to the value that is offered to the customer, and that is why this model is not suitable for complex analysis.

David Watson shows and evaluates a business model through six components: competitors, customers, economics, management, products and suppliers. It offers a new and unusual understanding of each component (Chesbrough H 2006: 37).

Competition is determined by barriers to market entry, the threat of substitute products, competition within the industry, and the advantage of being the first on the market. Customers are evaluated according to their characteristics, types of contracts and payment rates. The author emphasizes the advantage of continuously detecting gaps in the market. The company's economy is analyzed taking into account acquisitions, economies of scale, earnings from the growth of another company, dividends and breakpoints. Management is judged by morality, conflict checking, accounting rules, past successes and relationships with partners. Product analysis focuses on brand loyalty, competitive advantage, new product development, differentiation, sales points and value chain innovations. Suppliers are determined by their bargaining power and opportunistic buying.

This model is complex. Its uniqueness lies in the fact that the model analyzes industry factors, such as competition, which relate to the environment of the business model, but are not part of the components of the business model.

Consumer segments are defined by five types of markets: mass, segmented, niche, diversified and multilateral. The mass market is a large group of consumers with similar needs and problems. A segmented type divides customers into groups based on the same characteristics. There are products and services tailored to the customer in niche markets. Diversified markets are located in two or more industries with different needs and challenges. The multilateral type uses and interconnects segments (the VISA credit card provider creates relationships between three groups - banks, cardholders and merchants).

The basis of the business is the creation of primary value, which is defined in the mission of the company and describes the main product or service that the company sells to the client. The company adds to the primary cost also "additional value" (or a group of additional values), called value added, which increases the perception of a product or service for a client.

Companies that decide on sales channels can choose between sales through their own distribution network (Direct sales: store, seller, website, smartphone application, phone) or sales outsourcing (indirect: intermediary).

A standard customer relationship is personal assistance based on human interaction. The client 
communicates directly with the seller during the entire sale process.

A modification of this type consists in the allocation of personal assistance when the client receives the only agent who takes care of him. In the type of self-service, the company does not have any contact with the client, but simply provides a service or product. Automated services combine sophisticated customer service with automated processes (the Internet) and use a CRM system that recognizes a customer and can recommend a suitable product or service to him. Businesses are increasingly using communities to improve customer relationships. This type of relationship provides a free, quality database of observations directly from the customer. The modern type of relationship is co-creation, which makes relationships outside the standard, and the client becomes a co-creator of a product or service.

The component revenue stream describes cash flows. Among the most frequently used authors include the sale of goods and services. Leases and leases generate income from the granting of exclusive rights to use certain assets. Licensing generates money from granting customers permission to use protected intellectual property in exchange for license fees. Brokers earn on every trade. Advertising generates income from the provision of medial space.

Key resources include material resources (production facilities, buildings, vehicles and equipment) and intellectual resources (brand, knowledge, patents, copyrights, partnerships, customer databases and human resources - staff and managers). Key activities describe the most important activities related to value creation. This may be production, supply of products, design, marketing, sale (Mullins 2009: 28).

The key partner of the component describes the most important companies, authorities or people collaborating with the company. Optimization and economies of scale lead to partnerships that serve to reduce costs. The exchange of know-how, finances or technology encourages companies to join in partnerships. An example is Blue-ray technology, which was developed by a group of leading global electronics manufacturers, and after research and development, they began to sell their Blue-ray products individually. The acquisition of resources and activities also encourages companies to seek partners, because companies do not own all the necessary resources or do not perform all the necessary actions for their business. For example, insurance companies have brokers who sell products, and the insurance company can engage in core business. Costs represent the cash bonus of production.

The main goal of this work is to refine and systematize the latest theoretical knowledge about business models, develop their critical analysis, select an effective visualization method and study the properties of real business models.

The visualization tool $\underline{\mathrm{R}}$ (Image 1) - powerful free software environment for statistical computing and graphics creation. $\mathrm{R}$ is the most complex of the tools listed here.

As a statistical compilation used to analyze large data sets, $\mathrm{R}$ is a very complex tool that takes time to learn, but offers powerful support from other specialists and a batch library that is constantly expanding - Picture 3 :

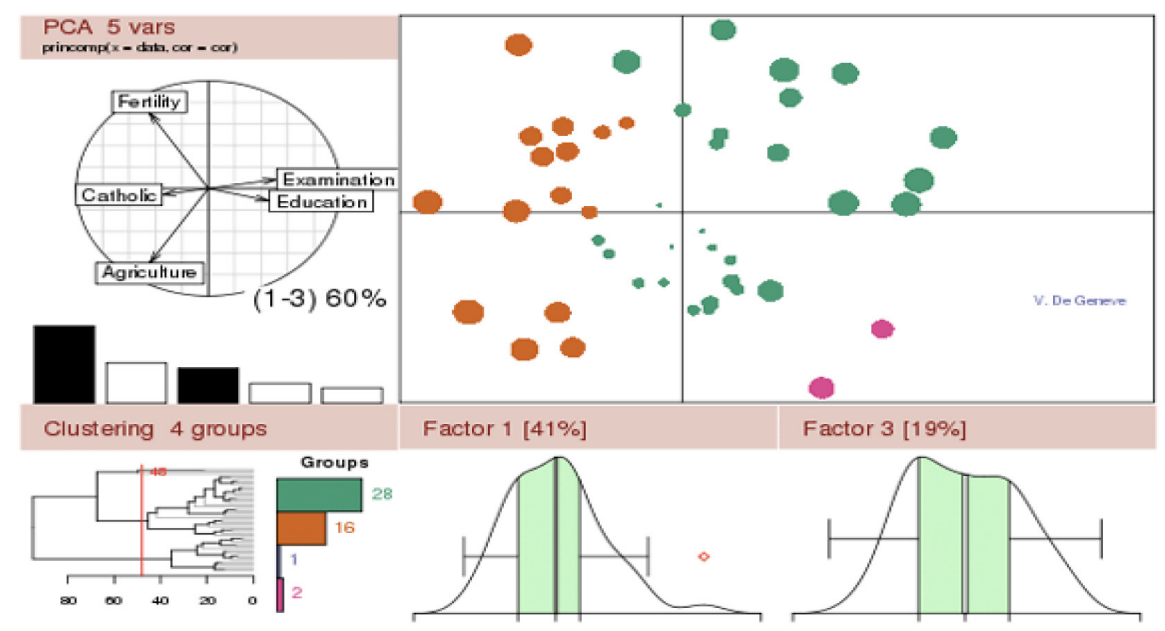

Picture 3 - Visualization tool $\mathrm{R}$ 
The studied sample was analyzed quantitatively and qualitatively. Quantitative analysis consists in measuring the frequency of occurrence of certain signs of a business model. The advantage of this type of research is a wide range of answers, and the disadvantage is less detailed information. Qualitative research allows you to very deeply know the causes and correlations. The questionnaire was sent to managers or specialists of the internal business with sufficient reliable knowledge.

Results and discussion. Results of the study of business models associated with the understanding of it the company earns a profit, it is necessary to structure its activities. From a financial point of view, the business model of any company can be described as the product of return on sales and asset turnover (capital). Some companies operate with low return on sales and high turnover. Others - with high profits and low turnover. In this case, the result of business models and managerial decisions made is measured by return on equity ( $\mathrm{ROE}=$ profit: equity). Having decomposed this indicator into components, we can conduct a multivariate analysis of the business model of companies to identify their advantages, as well as understand what factors the business model creates the value of companies. After all, the business model generates certain cash flows that affect the market value of the company, which can be defined as discounted future income streams. Such an analysis is also important because not every company making a profit creates value (Zucchella 2012:368).

Return on equity depends on three factors:

return on sales by net profit, asset turnover and financial dependency ratio. They characterize the operating (profitability of the enterprise), investment (how assets are used) and financial activities of the enterprise (sources of financing assets).

Where

$\mathrm{NP}$ - net profit;

E - equity;

$\mathrm{R}$ - revenue;

$\mathrm{A}-$ assets

We will conduct a comparative analysis of the business model of two competing companies Snickers and Mars based on their main financial indicators (Table 1):

Table 1 - Comparative analysis of Snickers and Mars (Dupont method)

\begin{tabular}{|c|c|c|c|c|}
\hline No. & Index & Formula & Snickers & Mars \\
\hline 1 & Revenue, billion US dollars & & 46.5 & 66.5 \\
\hline 2 & Net profit, billion US dollars & & 8.6 & 6.4 \\
\hline 3 & Assets, billion US dollars & & 80 & 72.8 \\
\hline 4 & $\begin{array}{c}\text { Carrying amount of equity, billion } \\
\text { US dollars }\end{array}$ & & 31.6 & 20.7 \\
\hline 5 & ROE (Return on Equity), $\%$ & $\mathrm{ROE}=\mathrm{NP}: \mathrm{E}$ & 27 & 31 \\
\hline 6 & Return on sales in net profit, $\%$ & $\begin{array}{c}\text { Return on sales by net profit } \\
\text { = NP: } \mathrm{R}\end{array}$ & 18 & 10 \\
\hline 7 & Asset turnover (assetutilization) & Asset turnover $=\mathrm{R}: \mathrm{A}$ & 0.58 & 0.91 \\
\hline 8 & $\begin{array}{l}\text { Coefficient of financial } \\
\text { independence }\end{array}$ & $\begin{array}{l}\text { The coefficient of financial } \\
\text { independence = A: NP }\end{array}$ & 2,53 & 3,52 \\
\hline
\end{tabular}

The table shows that the volume of assets and net profit in Mars is less than in Mars (lines 3 and 2), but ROE Mars is higher than Snickers (line 5). The factor analysis of return on equity (lines 6,7 and 8) allows us to understand why Mars has a higher ROE. This is mainly due to financial activities and more efficient management of company assets. To finance its activities, this company attracts more borrowed capital and its business model is more aimed at accelerating turnover (line 8). Together, these factors enable her to achieve a higher ROE. And Snickers business model is primarily focused on obtaining high margins. These indicators allow you to see how the business model of companies works in the 
first approximation. However, much remains incomprehensible. For example, whereby Snickers achieves higher sales profitability: at the expense of a lower share of cost or due to more efficient management of business and administrative expenses? Or why does Mars manage assets more efficiently - due to quick inventory turnover or efficient use of fixed assets? To answer these questions, a more detailed analysis is needed (Rappa
M 2010:39). The relationship of the model of the arzgamma and the elements of the business model for a qualitative analysis, the business model must be dived even deeper. To do this, you can use the 9-element approach to the analysis of the business model. Relationship factors and elements of the business model is shown in the matrix elements of the relationship business model and factors arzgamma model (Table. 2):

Table 2 - The matrix of the relationships of the elements of the business model and factors of the model of the arzgamma

\begin{tabular}{|c|c|c|c|c|c|c|c|}
\hline \multicolumn{3}{|c|}{ Cost Structure } & \multicolumn{4}{|c|}{ Revenue streams } & \\
\hline 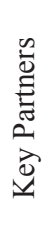 & 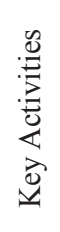 & 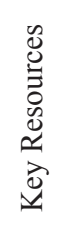 & 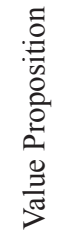 & 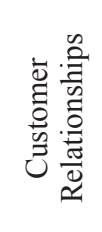 & 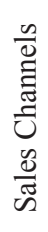 & 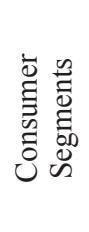 & \\
\hline$*$ & * & $*$ & & & & * & Gross Margin (F1) \\
\hline \multirow[t]{2}{*}{ * } & & $*$ & & * & * & & $\begin{array}{l}\text { The effect from commercial and administrative } \\
\text { expenses (F2) }\end{array}$ \\
\hline & & & & & & & The effect from financial activities (F3) \\
\hline$*$ & & & & & & & The tax effect (F4) \\
\hline$*$ & & & & & & & Money management, days (F5) \\
\hline * & & & & & * & & Accounts receivable management, days $(\mathrm{F} 6)$ \\
\hline$*$ & & & & & $*$ & & Inventory management, days (F7) \\
\hline$*$ & & & & & $*$ & & Management of other current assets, days (F8) \\
\hline * & & $*$ & & & $*$ & & Fixed assets management (F9) \\
\hline \multirow[t]{3}{*}{$*$} & & $*$ & & & $*$ & & Management of other non-current assets (F10) \\
\hline & & $*$ & & & & & Debt load (F11) \\
\hline & & $*$ & & & & & Interest-free liabilities (F12) \\
\hline
\end{tabular}

For example, distribution channels directly affect selling expenses and the management of cash, receivables, inventory and fixed assets. And consumer segments can have a strong impact on gross margin. Crosses in the matrix indicate explicit connections. However, the relationships of the business model are not linear and it is impossible to say exactly which element of the business model needs to be examined in more detail after a comparative analysis. Using the matrix along with the arzgamma allows you to select the elements of the business model that need to be studied first. In our example, Mars needs to look for lag by factors
F1, F2, F11 and F12, first of all, in the following elements of the business model - key partners, key resources, customer relationships, sales channels, key activities, consumer segments. And Snickers according to the factors F5, F7, F8 and F10 in such elements of the business model as key partners, distribution channels, key resources.

Conclusion. The dynamics and evolution of the current business environment are pushing companies to think fundamentally about the reasons and conditions for its existence. Visualization, analysis and reconstruction of a business model are strategic processes that must be created before 
formulating a strategy. The definition of a business model is a condition of the order and system of each business. The key theme is the value offered to the client, which helps him solve his problem. The solution is implemented on the basis of resources and business processes and delivered to the customer through channels and communications. A model is functional and attractive to a company if it can appropriate a part of the produced value.

A study of business models revealed several key findings characterizing the mainstream business. Consumer segmentation is determined by industry and product type. Consumer value is always a combination of several interrelated values, but in general one of them is the most important. Personal contact as a distribution channel is one of the most effective, but the website is the cheapest. In relations with clients, personal relations prevail between traders and clients. The choice of relationship depends on the complexity of the product and value added. Income streams usually have several sources, and the type of income depends on the type of business. The key sources are mainly those that are formed and cultivated for a long time and are intangible, such as knowledge, experience, workers and managers. Key opportunities are characterized by an apparent mismatch between the importance and quality of opportunities. There are important communications, speed, management system and innovation. The business model is built on key activities, which are sales, marketing, production (operation) and is supported by human resource management, infrastructure and procurement.

Key partners serve to procure resources and activities, as well as to form business alliances. Most enterprises are between a cost-based model and a cost-based model, with a tendency to a cost-based model. The most expensive resources ( $2 / 3$ of the cost) are machines, technologies and workers. The most costly activities (2/3 of the costs) are production, input logistics, warehousing and marketing. The development of new technologies is constantly making fundamental changes to the stagnant forms of business models that work on long-term stable principles and have undergone only minor modifications. Further research should be aimed at identifying new features, deviations, extremes and trends in each block of the business model. It is necessary to develop new research materials on innovative business models and study the conditions, places and ways of introducing innovations.

\section{References}

Afuah, A. (2003). Business Models: A Strategic Management Approach. New York: McGraw-Hill/ Irwin. Baden-Fuller, CH. \& Morgan, M. S. (2010).

Chesbrough, H. (2006). Open Business Models: How to Thrive in the New Innovation Landscape. Boston: Harvard Business School Press. Debelak, D. (2006).

DaSilva, M.C. and P. Trkman, 2013.LongRangePlanning. Business Model: What It Is and What It Is Not (1-11).

Johnson, W. M., Christensen, C. M. \& Kagerman, H. (2008). Reinventing Your Business Model. Harvard business review, 86(12), 57-68.

Korošová, V. \& Synek, V. (2011). Grécky oikos a nevalný val. Trend, No. 29

Magretta, J. (2010). Why Business Models Matter. Harward Business Review on Business Model Innovation. USA: HBR Publishing Corporation.

Mullins, J. \& Komisar, R. (2009). Getting to Plan B: Breaking Through to a Better Business Model. USA: Harvard Business Press.

Onetti, A., A. Zucchella, V.J. Marian and P.P. McDougall-Covin, 2012. Journal of Management and Governance. Internationalization, innovation and entrepreneurship: business models for new technology-based firms, Journal of Management \& Governance, 3: 337-368.

Rappa, M. (2010). Business Models on the Web. Retrieved May 17, 2010, from http:// digitalenterprise.org/models/models.html 1.

2. 3. 4. 5. 6. 7. 8. 9. 10. 11. 12. 13. 14. 15. joc4-2014_v3b.indd 39 30.12.2014 17:11:25 40 Journal of Competitiveness

Slávik, Š. (2011). Komparatívna analýza podnikatel'ských modelov. Ekonomika a manažment, 11(3), 23-43.

Slywotzky, A.J., 1996. Value Migration, Harvard Business Review Press,Boston,MA.

Teece, J. D. (2010). Business Models, Business Strategy and Innovation. Long Range Planning, 43(2), 172-194. http://dx.doi. org/10.1016/j.lrp.2009.07.003

Watson, D. (2005). Business Models. Petersfield: Harriman House Ltd.

Xavier L., D. Benoit and J. Ventura, 2010. M@n@gement. Business Models as a Research Program in Strategic Management: An Appraisal based on Lakatos, vol. 13 no. 4: 214-225.

Zott, C., R.Amit and L. Massa. The business model: theoretical roots, recent developments, and futurere search,IESEBusinessSchoolUniversityofNavarra, 2010.

Zott, C. and R. Amit, 2010.LongRangePlanning. Business Model Design: An Activity System Perspective, 43: $216-226$

VoelpelS.C., M. Leibord and E.B. Tekie, 2004. The wheel of business reinvention: how to reshape your business model to leapfrog competitors. Journal of change management, 4 (3): 259-276. 